\title{
Yield and quality of two sugar beet (Beta vulgaris L. ssp. vulgaris var. altissima Döll) cultivars are influenced by foliar application of salicylic acid, irrigation timing, and planting density
}

\author{
Khaled A.A. ABDELAAL ${ }^{1}$, Sahar H. RASHED ${ }^{2}$, Akbar HOSSAIN ${ }^{3}$, Ayman EL SABAGH ${ }^{4,5}$
}

Received May 16, 2019; accepted March 12, 2020.

Delo je prispelo 16. maja 2019, sprejeto 12. marca 2020

\begin{abstract}
Yield and quality of two sugar beet (Beta vulgaris L. ssp. vulgaris var. altissima Döll) cultivars are influenced by foliar application of salicylic acid, irrigation timing, and planting density
\end{abstract}

Abstract: Two field experiments were conducted to evaluate the time of foliar application of $100 \mathrm{ppm}$ salicylic acid (SA), two irrigation (IR) timings, three levels of spacing (SP) hill ${ }^{-1}$ with different plant density on growth, yield and quality characters of two sugar beet cultivars ('Samba' and 'Farida'). The results revealed that the foliar application of $100 \mathrm{ppm} \mathrm{SA}$ at 30 days after planting (DAP) and 14 days after the first application significantly influenced top fresh mass and root biomass of sugar beet plants. Conversely, the increasing period between planting and first irrigation scheduling led to significant differences in fresh mass, sugar yield, and sucrose $\%$ as well as purity $\%$ of sugar beet. Plants density with $60 \times 20 \mathrm{~cm}^{\text {spacing hill }}{ }^{-1}$ was found to be better than the other two spacings for major characters, particularly root fresh mass, and Total soluble solids and purity \%. Inversely, spacing at $60 \times 15 \mathrm{~cm}$, between hills gave the maximum levels of top fresh mass, root yield and sugar yield in the first season. The interaction effect between spacing hill $^{-1}$ at $60 \times 20 \mathrm{~cm}$ and $100 \mathrm{ppm} \mathrm{SA}$ applied at $30 \mathrm{DAP}$ gave the maximum levels of increment for most of the studied characters, particularly for cultivar 'Farida'.

Key words: planting density; sugar quality; salicylic acid; sugar beet; irrigation timing; yield
Vpliv foliarnega dodajanja salicilne kisline, časa namakanja in gostote setve na pridelek in kakovost dveh sort sladkorne pese (Beta vulgaris L. ssp. vulgaris var. altissima Döll)

Izvleček: Izvedena sta bila dva poljska poskusa za ovrednotenje vpliva časa foliarnega dodajanja 100 ppm salicilne kisline (SA), dveh terminov namakanja (IR), treh gostot setve (SP), na pridelek in kakovostne parametre dveh sort sladkorne pese ('Samba' in 'Farida'). Rezultati so pokazali, da je foliarno dodajanje 100 ppm SA 30 dni po setvi (DAP) in 14 dni po prvi uporabi DAFA značilno vplivalo na svežo maso nadzemnih delov in biomaso korenov sladkorne pese. Naraščanje časa med setvijo in prvim zalivanjem je privedlo do značilnih razlik $\mathrm{v}$ sveži masi, pridelku sladkorja, $\mathrm{v}$ odstotku saharoze in $\mathrm{v}$ čistosti posevka sladkorne pese. Gostota z razmakom rastlin $60 \times$ $20 \mathrm{~cm}$ se je izkazala boljša od ostalih dveh za večino merjenih lastnosti, še posebej v sveži masi korenov, v odstotku TSS in odstotku čistosti. Obratno je dal razmak $60 \times 15 \mathrm{~cm}$ največjo svežo maso nadzemnih delov, pridelka korenov in sladkorja $\mathrm{v}$ prvi sezoni. Interakcija gostote setve $60 \times 20 \mathrm{~cm}$ in dodatek 100 ppm SA 30 dni po setvi je dala največje vrednosti vseh preučevanih znakov, še posebej pri sorti 'Farida'.

Ključne besede: gostota setve; kakovost sladkorja; salicilna kislina; sladkorna pesa; režim namakanja; pridelek

Kafrelsheikh University, EPCRS Excellence Center, Faculty of Agriculture, Department of Agricultural Botany, Egypt

2 Soil, Water and Environment Research Institute, Agricultural Research Center, Giza, Egypt

3 Bangladesh Wheat and Maize Research Institute, Dinajpur, Bangladesh

4 Kafrelsheikh University, Department of Agronomy, Egypt

5 Corresponding author, e-mail: ayman.elsabagh@agr.kfs.edu.eg 


\section{INTRODUCTION}

Sugar beet (Beta vulgaris L. ssp. vulgaris var. altissi$m a$ Döll) is a temperate crop also cultivated in subtropical countries. It is generally considered as a crop of temperate region, however, it is largely cultivated also in sub-tropical countries, where it can be grown successfully during the winter season (Brar et al., 2015). It is a biennial plant and one of the most essential sugar crops. The global cultivated area of sugar beet in 2014 was 4.47 million ha with a total root yield of 266.8 million tons (FAOSTAT, 2016). In Egypt, the cultivated area in the year 2016 was 254, 991 ha with the root yield of 13.3 million tons (FAOSTAT, 2016). Sugar beet is a widely adaptive crop and grows in multiple agro-ecological conditions. It takes a shorter period to maturity than the sugar cane plant and also productivity per unit time is higher and requires less water than sugarcane (Brar et al., 2015). Many environmental and agronomic factors such as biofertilization, irrigation, planting spacing sowing methods had influenced the production and quality of sugar beet (Abdelaal, 2015a; Abdelaal and Tawfik, 2015; Omar et al., 2019a,b). The main target for growers and sugar companies is to improve their quality and increase the extracted sugar (Awad et al., 2013). Therefore to get maximum benefits from sugar beet, there is a need to select the most appropriate varieties, to reduce planting time, to optimize planting methods, planting density, sowing depth as well as to provide adequate crop nutrition and irrigation schedule (Seadh et al., 2013; Brar et al., 2015).

However, among the abiotic stresses, water deficit is one of the most environmental factors threatening the agricultural production and the main reason of crop loss worldwide, reducing morphological characters and yield components of plants (Abdelaal, 2015b; EL Sabagh et al., 2019a). Due to drought stress the growth duration, growth, and development, as well as yield, are decreased (EL Sabagh et al., 2019e). Furthermore, under drought stress, the accumulation of osmoprotectants like proline is noticed (EL Sabagh et al., 2019d).

Reduced photosynthetic rates of plants have a direct effect on growth characters such as decrease dry mass and leaf area (Gong et al., 2005). Under drought stress, nitrogen metabolism, enzyme activities and protein synthesis can be impaired (Saneoka et al., 2004). However, plants have many mechanisms to adjust abiotic stress by changing the morpho-physiological characters (Todaka et al., 2012; Molla et al., 2019; Yassin et al., 2019). Neseim et al. (2014) found that under drought stress, morphological characters such as root yield and white sugar/fedden (0.42 ha) were significantly reduced, whereas, total soluble phenols and free amino acid concentrations in leaves and roots were significantly increased that ultimately led to surviving under stress condition.

It was previously reported, that root diameter, percentage of sucrose, and root yield, as well as sugar yield ( $\mathrm{t} /$ fedden $(0.42 \mathrm{ha})$ ) of sugar beet, increased significantly with larger plant spacing from 20 to $30 \mathrm{~cm}$ (Nafei et al., 2010; Shalaby et al., 2011). While, Ramazan (2002) observed that root yield and sugar content were the highest at closer planting density of 103600 plants/ha (i.e $45 \times$ $20 \mathrm{~cm}$ spacing), as compared to $555000(45 \times 40 \mathrm{~cm})$, $73000(43 \times 30 \mathrm{~cm})$ and $88900(45 \times 25 \mathrm{~cm})$ plants ha- ${ }^{-1}$. Similarly, Bhullar et al. (2010) reported that the highest root and sugar yield of sugar beet were produced from the planting density at $1,00,000$ plants ha- $\mathrm{a}^{-1}(50 \times 20 \mathrm{~cm})$ as compared with planting densities 83,333 plants ha ${ }^{-1}(60 \mathrm{x}$ $20 \mathrm{~cm})$ and $1,11,111$ plants ha- ${ }^{-1}(60 \times 15 \mathrm{~cm})$.

The previous studies have reported that the application of osmoprotectants under stressful environment (biotic and abiotic) help to maintain plant growth and yield. Moreover, osmoprotectants led to alleviate the injurious effect of stress conditions and enhance the growth characters and yield parameters of different crops moreover, it helps to survive under different biotic and abiotic stress. (El?? Sabagh et al., 2019 b,c).

Salicylic acid (SA) is recognized as a phytohormone produced after a chain of chemical reactions as benzoic acid derivative and plays a vital role in many physiological process such as photosynthesis, nutrient uptake, membrane permeability and also help to survive under different biotic and abiotic stress playing a key role in systemic acquired resistance (Noreen et al., 2009; Abdelaal, 2015b). Moosavi (2012) and Abido et al. (2015) observed that foliar spray of SA led to improve plant growth characters and enhanced the tolerance capacity of plants under abiotic stress as well as it protects the plant from oxidative stress by increasing antioxidant enzymes activity, finally increasing the fresh root and shoot mass of sugar beet and sunflower plants (Merwad, 2015; Noreen et al., 2017a,b). Furthermore, However, the foliar application of $100 \mathrm{mg} \mathrm{l}^{-1}$ SA gave the highest values for growth characters of stevia plants (reported by El-Housini et al., 2014); soybean plants (Mishra and Prakash, 2013).

There is an insufficient amount of information about the effect of SA on sugar beet growth and productivity that are linked to water deficit and density population under field conditions. The main target for the cultivation of sugar beet is to extract sugar of high yield and quality. Therefore, to get maximum benefits from sugar beet there is a need to select the most appropriate varieties, planting methods, planting density, providing adequate crop nutrition and irrigation schedule. Considering the important issues, two field experiments were conducted to evaluate the foliar application of $100 \mathrm{ppm}$, irrigation 
(IR) and spacing (SP) on growth, yield and quality characters of two sugar beet cultivars ('Samba' and 'Farida').

\section{MATERIALS AND METHODS}

\subsection{EXPERIMENTAL SITES}

Two field experiments were conducted at Kalabsho, El-Dakahlia Governorate, Egypt $\left(30^{\circ} 35^{\prime} 41.9^{\prime \prime} \mathrm{N}\right.$ latitude and $32^{\circ} 16^{\prime} 45.8^{\prime \prime} \mathrm{E}$ longitude) in consecutive two winter seasons 2016-17 and 2017-18. The area is characterized by a short warm-winter and long-hot summer. The annual average rainfall and relative humidity are about $40.4 \mathrm{~mm}$ and $65.4 \%$. The area of study exhibits certain desertification features because the surface Nile water does not adequately reach to the ends of canals. Groundwater is the major source of irrigation.

\subsection{EXPERIMENTAL TREATMENTS, DESIGN AND PLANT MATERIALS}

Two sugar beet cultivars namely 'Farida' and 'Samba' were used in the experiment. Treatments included:

three levels of plant density such as 44465 plants/ fedden (0.42 ha), 33335 plants/fedden (0.42 ha), and 26665 plants/fedden ( $0.42 \mathrm{ha})$;

three types of plant spacing (SP) hill ${ }^{-1}$ such as at $60 \mathrm{x}$

$15 \mathrm{~cm}, 60 \times 20 \mathrm{~cm}$ and $60 \times 25 \mathrm{~cm}$;

foliar application of $100 \mathrm{ppm} \mathrm{SA}$, applied at $30 \mathrm{DAP}$ and 14 days after the first application,

and two irrigations (IR) times, one applied at 20 DAP and another one applied at 30 DAP.

All treatments were arranged in a split-split plot design and repeated four in four blocks to minimize the biasness.

To minimize the experimental errors, two irrigations' times (IR) were arranged in main plots, while hill spaces (spacing (SP) hill ${ }^{-1}$ with three levels of plant density were arranged in sub-plots and two sugar beet cultivars were located in sub-sub-sub plots.

\subsection{EXPERIMENTAL PROCEDURE}

Four seeds were sown in hills on $4^{\text {th }}$ and $3^{\text {rd }}$ October in 2016-17 and 2017-18 seasons. Each sub-plot contained 6 rows, which were $60 \mathrm{~cm}$ apart. Potassium at $24 \mathrm{~kg} \mathrm{~K} \mathrm{O} /$ fedden (0.42 ha) and phosphorus at $30 \mathrm{~kg} \mathrm{P}_{2} \mathrm{O}_{5} /$ fedden (0.42 ha) were applied in the soils during final land preparation. Ammonium nitrate $(33.5 \% \mathrm{~N})$ at $100 \mathrm{~kg} \mathrm{~N} / \mathrm{fed}-$ den $(0.42 \mathrm{ha})$ was added at two equal doses after thinning and one month later after the first application. Foliar application of 100 ppm SA was applied 30 DAP and 14 days after the first application (DAFA). Harvest date was after 210 days from sowing.

\subsection{DATA COLLECTION}

\subsubsection{Morphological characters}

At harvesting time ten plants were randomly taken from each sub-sub-sub plot to determine morpho-physiological and yield characters. Morphological characters such as root diameter $(\mathrm{cm})$, root fresh mass $\left(\mathrm{kg} \mathrm{plant}^{-1}\right)$ and top fresh mass $\left(\mathrm{kg} \mathrm{plant}^{-1}\right)$ were recorded.

\subsubsection{Yield and quality evaluation}

Total soluble solids (TSS \%) were estimated in the juice of fresh roots by using Hand Refractometer. Sucrose percentage (\%) was determined polarimetrically on lead acetate extract of fresh macerated roots according to the method of (Le Docte, 1927; Dutton et al., 1961). Apparent purity percentage (\%) was determined as a ratio between sucrose $\%$ and TSS \% of roots. Sugar beet plants from each plot were harvested topped to calculate root yield and top yield $(\mathrm{t} /$ fedden $(0.42 \mathrm{ha}))$. Sugar yield ( $\mathrm{t} /$ fedden $(0.42 \mathrm{ha})$ ) was calculated as follows: Sugar yield $(\mathrm{t} /$ fedden $(0.42 \mathrm{ha}))=$ Root yield $(\mathrm{t} /$ fedden $(0.42 \mathrm{ha})) \mathrm{x}$ sucrose $\%$.

\subsection{STATISTICAL ANALYSES}

Data represent the mean $\pm \mathrm{SD}$. The student's $\mathrm{t}$-test was used to determine whether significant difference $(p<0.05)$ existed between mean values according to O'Mahony (1986).

\section{RESULTS AND DISCUSSION}

\subsection{YIELD AND QUALITY PARAMETERS OF SUGAR BEET ARE INFLUENCED BY SA, IRRI- GATION TIMES, DIFFERENT SPACINGS AND CULTIVARS}

After two years of observation, the results of the study revealed that foliar application of $100 \mathrm{ppm} \mathrm{SA}$ at 30 DAP and 14 DAFA significantly influenced the top fresh mass and root biomass of sugar beet plants under both the two growing seasons. Conversely, the increasing 


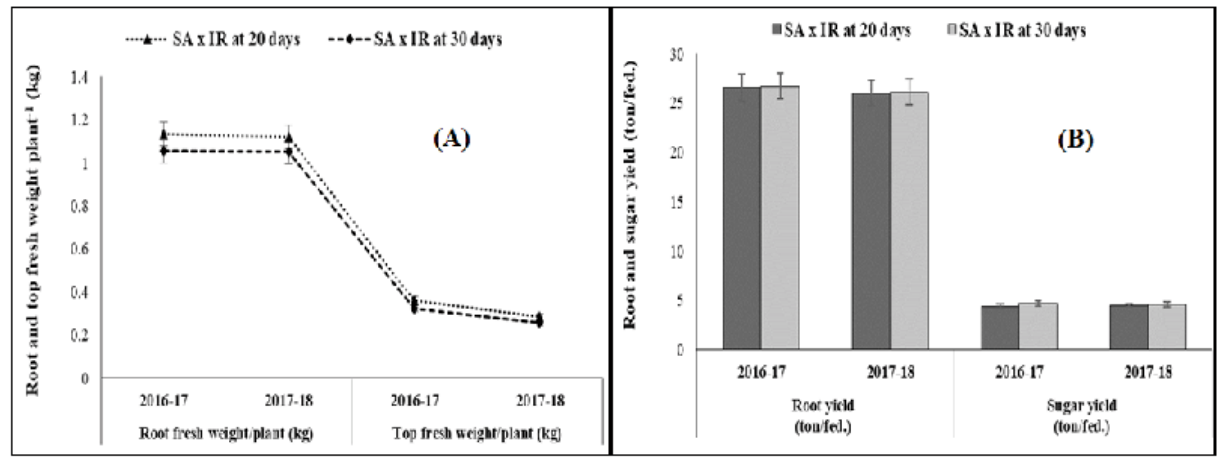

Figure 1: (A): Root and top fresh mass plant ${ }^{-1}$ of sugar beet are influenced by SA (applied at 30 DAP and 14 days after first application), and irrigation (IR) at 20 and 30 DAP. (B): Root and sugar yield (t/fedden ( $0.42 \mathrm{ha})$ of sugar beet are influenced by the application of SA (applied at 30 DAP and 14 days after first application), and irrigation (IR) at 20 and 30 DAP.

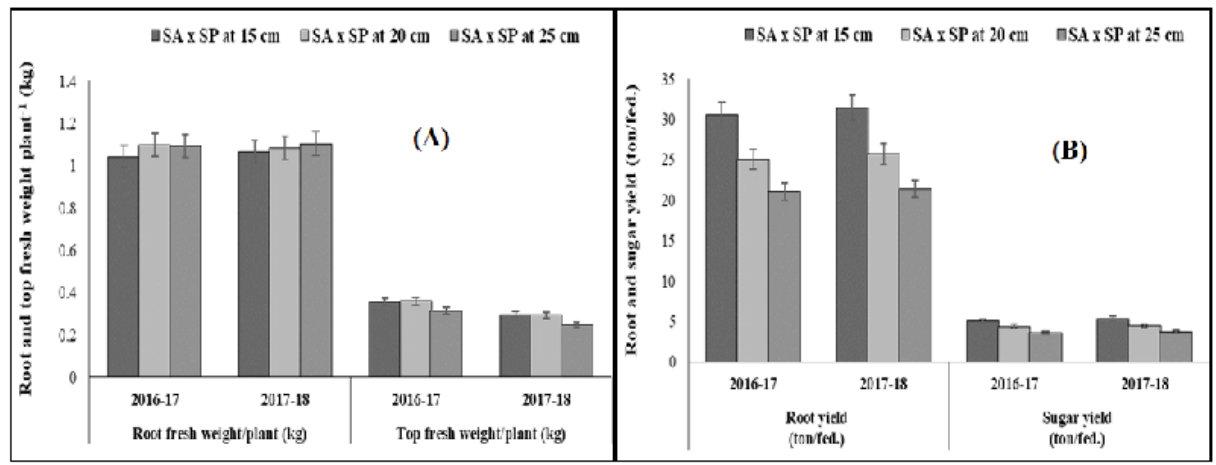

Figure 2: (A): Root and top fresh mass plant ${ }^{-1}$ of sugar beet are influenced by SA (applied at 30 DAP and 14 DAFA), and spacing (SP) hill ${ }^{-1}$ at $60 \times 15,60 \times 20$ and $60 \times 25 \mathrm{~cm}$. (B): Root and sugar yield (t/fedden $(0.42 \mathrm{ha})$ of sugar beet are influenced by SA (applied at 30 DAP and 14 DAFA), and spacing (SP) hill ${ }^{-1}$ at $60 \times 15,60 \times 20$ and $60 \times 25 \mathrm{~cm}$.

period of irrigation led to significant differences in fresh mass, sugar yield, and sucrose $\%$ as well as purity $\%$ in both the seasons (Figure $1(A \& B), 2(A \& B)$ and $3(\mathrm{~A} \& \mathrm{~B})$ ). Prolongation of irrigation to 30 days gave the highest values of sugar yield in the two seasons, whereas the increment of root and sugar yield was not significant in the first season (2016-17). The influence of prolonged period between last irrigation on morphological characters such as root fresh mass and top fresh mass are similar to the results which have been reported by Jain et al. (2010) and Abdelaal et al. (2017).

In the present study, planting at space $20 \mathrm{~cm}$ between hills with the application of SA was more promising than other spaces and gave the highest lev- els of root fresh mass and top fresh mass in both seasons. However, the increment of root and sugar yield was significant and obtained with SA and $15 \mathrm{~cm}$ space between hills. Regarding the effect of cultivars, the maximum levels of root fresh mass, top fresh mass, and root yield, as well as sugar yield, were obtained with the cultivar 'Farida' compared to 'Samba'. The results of the present study concerning cultivars are similar to the findings of Ramadan, (1999) and Awad et al (2012), who also observed significant variations between different cultivars, due to the application of SA, IR and also for SP.

Results presented in Figure 4 (A \& B) \& 5 (A) on the interaction effects between $100 \mathrm{ppm} \mathrm{SA}$, water regimes before harvest and hills' spacing were signifi- 


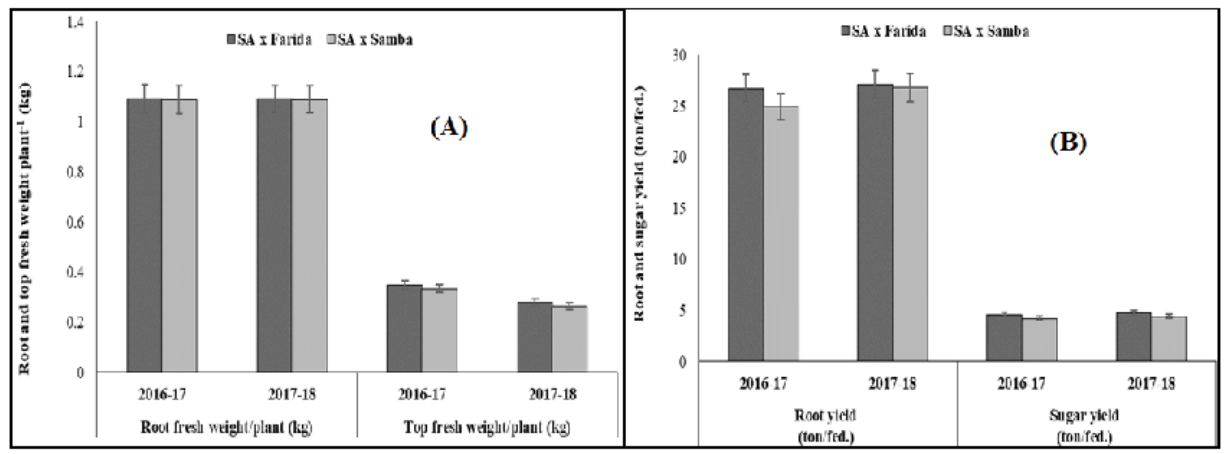

Figure 3: (A): Root and top fresh mass plant ${ }^{-1}$ of sugar beet are influenced by SA (applied at 30 DAP and 14 DAFA), and cultivars ('Farida' and 'Samba'). (B): Root and sugar yield ( $\mathrm{t} / \mathrm{fedden}(0.42 \mathrm{ha})$ ) of sugar beet is influenced by SA (applied at 30 DAP and 14 DAFA), and cultivars ('Farida' and 'Samba').

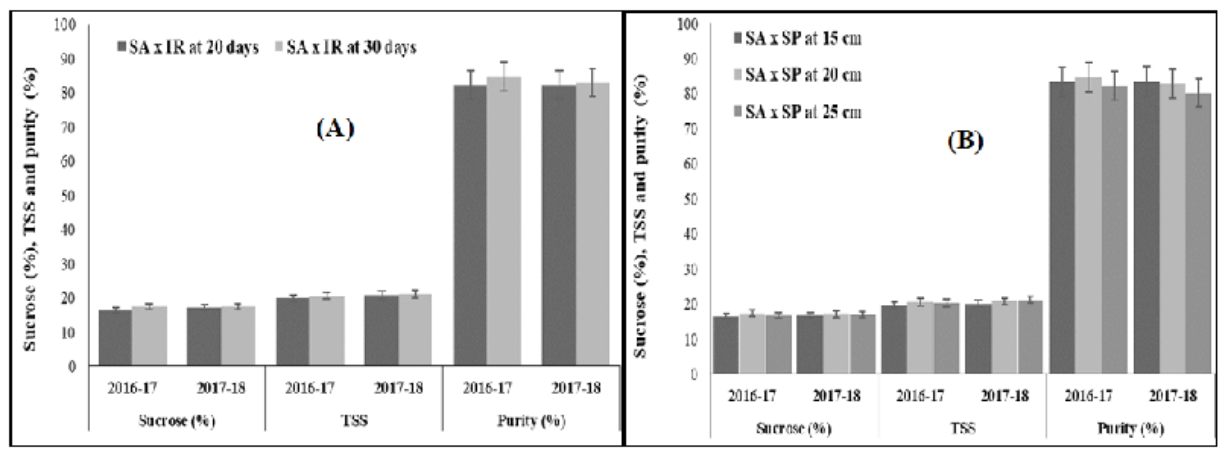

Figure 4: (A): Sucrose (\%), total soluble solids (TSS \%) and purity (\%) of sugar beet are influenced by SA (applied at 30 DAP and 14 DAFA), and irrigation (IR) at 20 and 30 days. (B): Sucrose (\%), TSS and purity (\%) of sugar beet are influenced by SA (applied at 30 DAP and 14 DAFA), and spacing (SP) hill-1 at $60 \times 15,60 \times 20$ and $60 \times 25 \mathrm{~cm}$.

cant on the most of the characters of sugar beet in both seasons under the study. Nevertheless, the interaction effects between SA, regime water and spacing hills were not significant on TSS \% in the second season only. The valuable effect of SA on root fresh mass, top fresh mass, and root yield may be due to its role in increasing chlorophyll concentration and enhancement photosynthetic process as well as decreasing the injurious effect of water deficit on plants Abdelaal (2015b). These effects are in agreement with those recorded by Azooz et al. (2011) and Kang et al. (2013). The authors found the relationship between SA, IR, and SP for root fresh mass, top fresh mass, root yield and also for sucrose (\%), TSS and purity (\%).

\subsection{YIELD AND QUALITY PARAMETERS OF SUGAR BEET ARE INFLUENCED BY IN- TERACTION EFFECT OF SA, IRRIGATION, SPACING, AND CULTIVARS}

The results of the current study presented in Figure $5(\mathrm{~B})$, and 6 (A \& B) revealed that the interaction effects between SA, last irrigation and hill spacing were significant on root fresh mass, top fresh mass, root and sugar yield, sucrose $\%$, TSS $\%$ as well as purity $\%$ in both seasons. The maximum values of root fresh mass, top fresh mass, root yield, and sugar yield were obtained with $\mathrm{SA}, 15 \mathrm{~cm}$ between plants and period between last irrigation and harvest date at 20 days in both seasons (Figure 5(B), 6(A)). Like- 


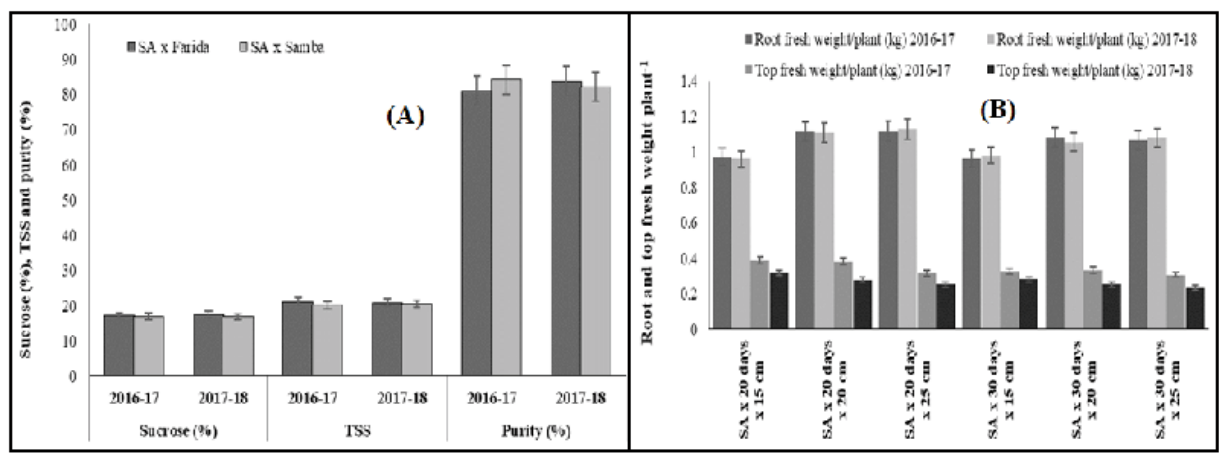

Figure 5: (A): Sucrose (\%), TSS and purity (\%) of sugar beet are influenced by SA (applied at 30 DAP and 14 DAFA), and cultivars ('Farida' and 'Samba'). (B): Root and top fresh mass plant ${ }^{-1}$ of sugar beet are influenced by interaction effect of SA (applied at 30 DAP and 14 DAFA), irrigation (IR) at 20 and 30 days, and spacing (SP) hill ${ }^{-1}$ at $60 \times 15,60 \times 20$ and $60 \times 25 \mathrm{~cm}$.

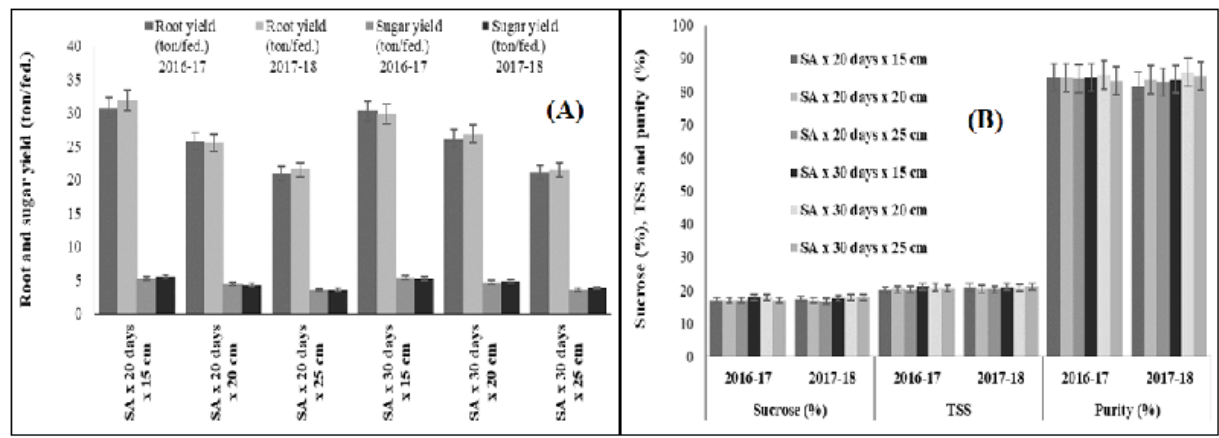

Figure 6: (A): Root and sugar yield ( $\mathrm{t} /$ fedden ( $0.42 \mathrm{ha}$ ) of sugar beet are influenced by interaction effect of SA (applied at $30 \mathrm{DAP}$ and 14 DAFA), irrigation (IR) at 20 and 30 days, and spacing (SP) hill ${ }^{-1}$ at $60 \times 15,60 \times 20$ and $60 \times 25 \mathrm{~cm}$. (B): Sucrose (\%), TSS and purity (\%) of sugar beet are influenced by interaction effect of SA (applied at 30 DAP and 14 DAFA), irrigation (IR) at 20 and 30 days, and spacing (SP) hill ${ }^{-1}$ at $60 \times 15,60 \times 20$ and $60 \times 25 \mathrm{~cm}$.

wise, the highest levels of sucrose $\%$, TSS \%, and purity $\%$ were obtained with the interaction between SA, the period between last irrigation and harvest date at 30 days and $20 \mathrm{~cm}$ between plants (Figure 6 (B)). It might be due to the reduction of competition between plants for light and nutrients, consequently improving plant growth and production (Nafei et al., 2010).

Referring to the effect of interaction between SA, the period between last irrigation and harvest date as well as cultivars on root fresh mass, root yield, sugar yield, and quality characteristics, presented data in Figures 7 (A \& B) displayed a significant effect on most characteristics in the two growing seasons. The maximum values of root yield, sugar yield, sucrose $\%$, and purity \% were recorded with the interaction between $\mathrm{SA}$, the period between last irrigation and harvest date at 30 days and 'Farida' cultivar compared with other treatments. Increasing the prevention period of water supply before harvesting led to increasing the concentrations of sucrose and purity \%. These results are in harmony with the achieved results by Sohrabi and Heidari (2008), who also found the maximum values of plant biomass such as root, top biomass, sugar yield due to the combined effect of SA, application times of irrigation and different crop cultivars.

Regarding to interaction effects between SA, hill spacing and cultivars on fresh mass of root, root yield, sugar yield, sucrose $\%$, TSS $\%$, and purity $\%$ obtained 


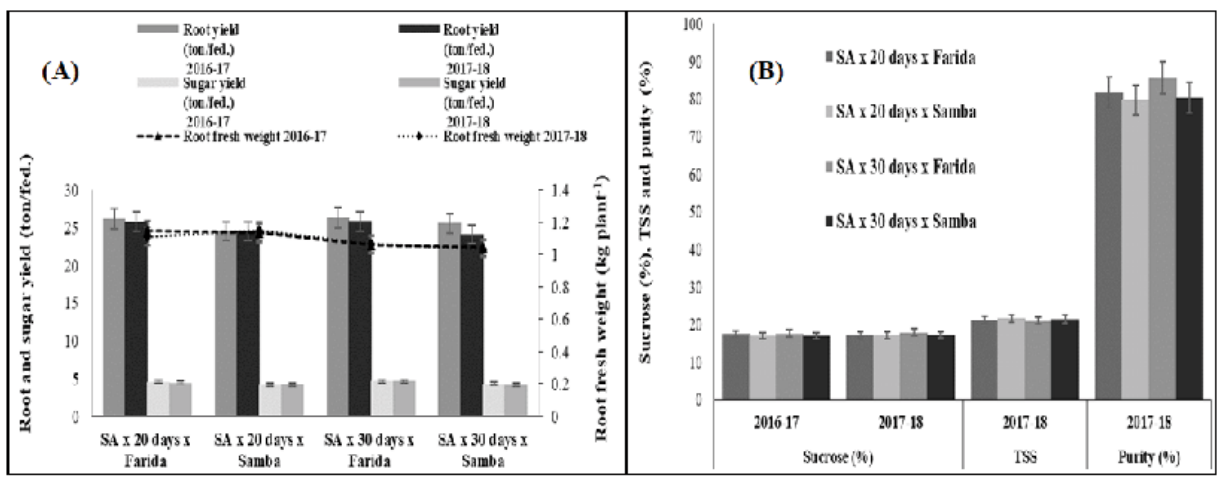

Figure 7: (A): Root fresh mass plant ${ }^{-1}(\mathrm{~kg})$, root yield ( $\mathrm{t} /$ fedden $(0.42 \mathrm{ha})$ and sugar yield ( $\mathrm{t} / \mathrm{fedden}(0.42$ ha)) of sugar beet is influenced by interaction effect of SA (applied at 30 DAP and 14 DAFA), irrigation (IR) at 20 and 30 days, and cultivars ('Farida' and 'Samba'). (B): Sucrose (\%), TSS and purity (\%) of sugar beet are influenced by interaction effect of SA (applied at 30 DAP and 14 DAFA), irrigation (IR) at 20 and 30 days, and cultivars ('Farida' and 'Samba').

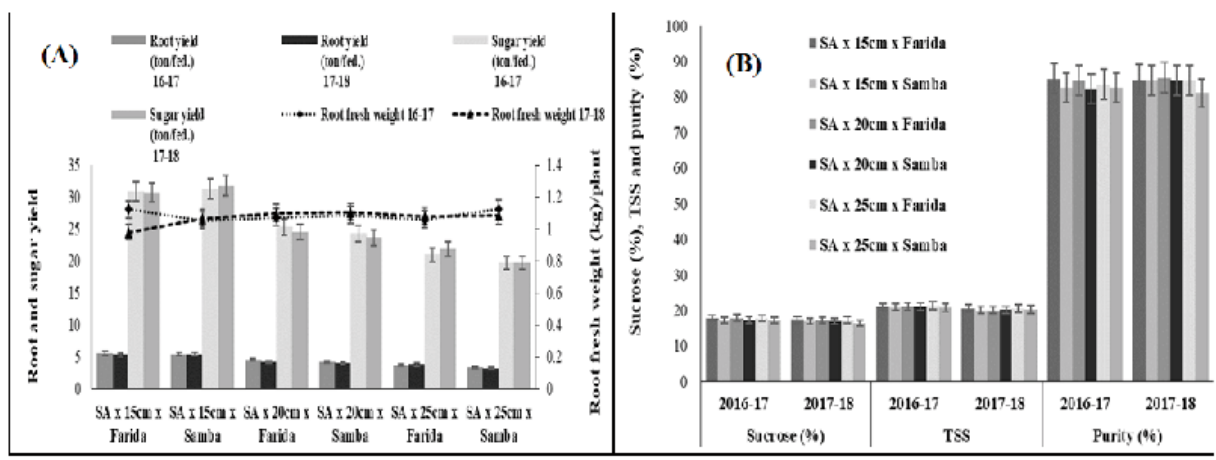

Figure 8: (A): Root fresh mass plant ${ }^{-1}(\mathrm{~kg})$, root yield $(\mathrm{t} /$ fedden $(0.42 \mathrm{ha}))$ and sugar yield ( $\left.\mathrm{t} / \mathrm{fedden}(0.42 \mathrm{ha})\right)$ of sugar beet is influenced by interaction effect of SA (applied at 30 DAP and 14 DAFA), spacing (SP) hill ${ }^{-1}$ at $60 \times 15,60 \times 20$ and $60 \times 25 \mathrm{~cm}$, and cultivars ('Farida' and 'Samba'). (B): Sucrose (\%), TSS and purity (\%) of sugar beet are influenced by interaction effect of SA (applied at 30 DAP and 14 DAFA), spacing (SP) hill ${ }^{-1}$ at 60 x15, 60 x 20 and $60 \times 25 \mathrm{~cm}$, and cultivars ('Farida' and 'Samba').

results in Figure 8 (A) showed that the maximum levels of fresh mass of root, root yield, and sugar yield were recorded at treatment interaction between $\mathrm{SA}, 15 \mathrm{~cm}$ hill spacing and 'Farida' cultivar as well as interaction between SA, $15 \mathrm{~cm}$ hill spacing and 'Farida' cultivar respectively in both season comparing with other treatments. The same trend was observed with the combined effect of SA, IR, plants' spacing and cultivars'(Ramadan, 1999; Shalaby et al., 2011). Furthermore, the maximum levels of sucrose $\%$ and purity $\%$ were obtained with the interaction between SA, $15 \mathrm{~cm}$ hill spacing and 'Farida' cultivar Figure 8 (B). The assumption is confirmed by several earlier findings but for different crops, who also revealed that application of SA influenced the growth, photosynthesis and carbohydrate metabolism of maize (Zhou et al., 1999; Khodary, 2004), sugar beet (Ghoulam et al., 2001) and sugarcane (Du et al., 1998) under stressed condition.

Results presented in Figure 9, clearly show that the highest levels of sucrose, root and sugar yield were recorded with the interaction between SA, the period between last irrigation and harvest date at 30 days, $15 \mathrm{~cm}$ spacing hills and 'Farida' cultivar. These findings are in agreement with the observation of Awad et al. (2014). The results may be due to the essential role of SA in the enhancement of cellular osmolytes and improve photosynthetic pigments as well as plant production under water deficit conditions (Abdelaal, 2015b). 


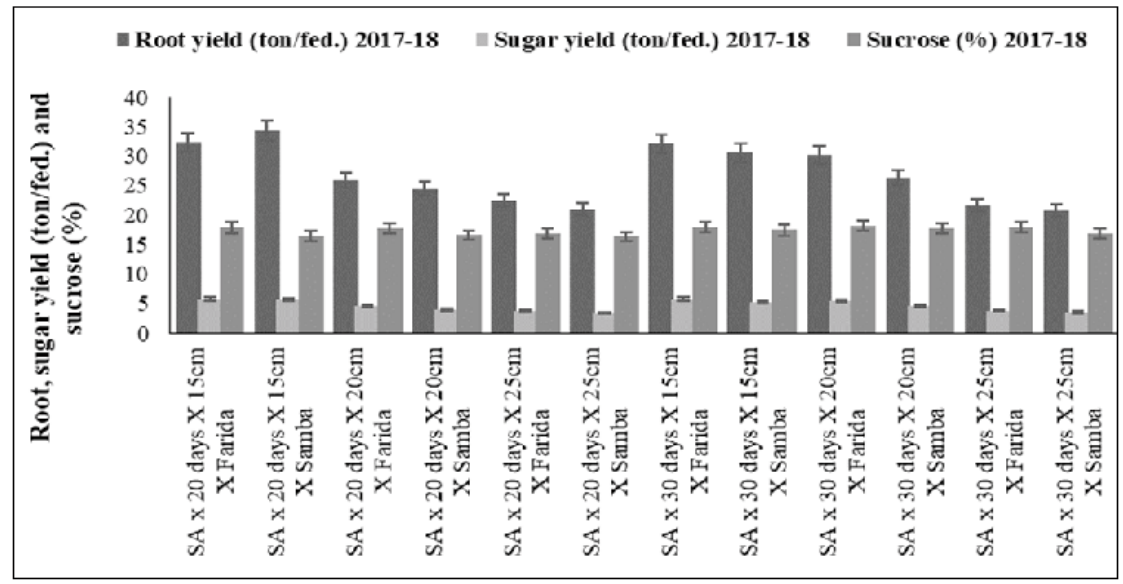

Figure 9: Root, sugar yield and sucrose (\%) of sugar beet are influenced by interaction effect of SA (applied at 30 DAP and 14 DAFA), irrigation (IR) at 20 and 30 days, spacing (SP) hill ${ }^{-1}$ at $60 \times 15,60 \times 20$ and 60 x $25 \mathrm{~cm}$, and cultivars ('Farida' and 'Samba').

\section{CONCLUSION}

Our results of the study suggest that the foliar application of 100 ppm SA at 30 DAP and 14 DAFA significantly influenced the top fresh mass and root biomass of sugar beet plants under both the two growing seasons. Conversely, the increasing period between planting and first irrigation led to significant differences in fresh mass, sugar yield, and sucrose $\%$ as well as purity $\%$ of sugar beet in both the seasons. Plants spacing hill ${ }^{-1}$ of 60 $\times 20 \mathrm{~cm}$ with 33335 plants/fedden (0.42 ha)) were found to be better than the other two spacings for most of the characters, particularly root fresh mass, and sucrose total soluble solids (TSS \%) and purity \%. Inversely, spacing at $60 \times 15 \mathrm{~cm}$ (with 44465 plants/fedden ( $0.42 \mathrm{ha}$ )), between hills gave the maximum levels of top fresh mass, root yield and sugar yield in the first season. The interaction effect between spacing hill-1 at $60 \times 20 \mathrm{~cm}$ (33335 plants/fedden (0.42 ha)) and 100 ppm SA applied at 30 DAP gave the maximum levels of increment for most of the studied characters, mainly for the cultivar 'Farida' than 'Samba'.

\section{ACKNOWLEDGEMENT}

This research was supported by Plant Pathology and Biotechnology Lab and EPCRS Excellence Centre (Certified according to ISO/17025, 9001, 14001 and OHSAS 18001) Department of Agricultural Botany, Faculty of Agriculture, Kafrelsheikh University, Kafr-Elsheikh, Egypt.

\section{REFERENCES}

Abdelaal, Kh.A.A. (2015a). Pivotal Role of Bio and Mineral
Fertilizer Combinations on Morphological, Anatomical and Yield Characters of Sugar Beet Plant (Beta vulgaris L.). Middle East Journal of Agriculture Research, 4(4), 717-734.

Abdelaal, Kh.A.A., \& Tawfik Sahar, F. (2015). Response of Sugar Beet Plant (Beta vulgaris L.) to Mineral Nitrogen Fertilization and Bio-Fertilizers. International Journal of Current Microbiology and Applied Sciences, 4(9), 677-688.

Abdelaal, Kh.A.A., (2015b). Effect of Salicylic acid and Abscisic acid on morpho-physiological and anatomical characters of faba bean plants (Vicia faba L.) under drought stress. Journal of Plant Production, Mansoura University, 6, 17711788. https://doi.org/10.21608/jpp.2015.52096

Abdelaal, Kh.A.A., Hafez, Y.M., EL Sabagh, A., \& Saneoka, H. (2017). Ameliorative effects of Abscisic acid and yeast on morpho-physiological and yield characteristics of maize plant (Zea mays L.) under water deficit conditions. Fresenius Environmental Bulletin, 26(12), 7372-7383.

Abido, W.A.E., Ibrahim, M.E.M., \& El-Zeny, M.M. (2015). Growth, Productivity and Quality of Sugar Beet as Affected by Antioxidants Foliar Application and Potassium Fertilizer Top Dressing. Asian Journal of Crop Science, 7(2), 113-127. https://doi.org/10.3923/ajcs.2015.113.127

Awad, N.M.M., Gharib, H.S., \& (2013). Response of Sugar Beet (Beta vulgaris L.) to Potassium and Sulphur Supply in Clayed Soil at North Delta, Egypt. Egyptian Jounal of Agronomy, 35(1), 77-91. https://doi.org/10.21608/agro.2013.94

Awad, N. M.M., Abdeldaiem, A., \& Moustafa, S.M. (2014). Evaluation of six sugar beet varieties under three harvesting dates. Minufiya Journal of Agricultural Research, 391(1), 121-130.

Awad, N.M.M., Sahar, Tawfik, F., \& Moustafa, S.M. (2012). Effect of plowing depth, sowing method and nitrogen fertilization on yield and quality of sugar beet. Journal of Agricultural Research Kafr-Elsheikh University,38(4), 458-470.

Azooz, M.M., Youssef, M.A., \& Parvaiz, A. (2011). Evaluation of salicylic acid (SA) application on growth, osmotic solutes and antioxidant enzyme activities on broad bean seedlings grown under diluted seawater. International Journal of 
Plant Physiology and Biochemistry, 3(14), 253-264. https:// doi.org/10.5897/IJPPB11.052

Bhullar, M.S., Uppal, S.K., \& Kapur, M.L. (2010). Influence of planting density and nitrogen dose on root and sugar yield of beet (Beta vulgaris L.) under sub-tropical semi-arid conditions of Punjab. Journal of Research Punjab Agricultural University, 47, 14-17.

Brar, N.S., Dhillon, B.S., Saini, K.S., \& Sharma, P.K. (2015). Agronomy of sugarbeet cultivation-A review. Agricultural Reviews, 36(3), 184-197. https://doi.org/10.5958/09760741.2015 .00022 .7

Du, Y.C., Nose, A., Wasano, K., \& Ushida, Y. (1998). Responses to water stress of enzyme activities and metabolite levels in relation to sucrose and starch synthesis, the Calvin cycle and the C4 pathway in sugarcane (Saccharum sp.) leaves. Australian Journal Plant Physiology, 25, 253-60. https://doi. org/10.1071/PP97015

Dutton, J.V., Carruthers, A., \& Oldfield, J.F.T., (1961). The synthesis of sucrose by extracts of the root of the sugar beet. Biochemical Journal, 81(2), 266-272. https://doi.org/10.1042/ bj0810266

EL Sabagh, A., Hossain, A., Barutçular, C., Islam M.S., Ratnasekera, D., Kumar, N., Meena, R.S., Gharib, H.S., Saneoka, H., \& Teixeira da Silva, J.A. (2019a). Drought and salinity stress management for higher and sustainable canola (Brassica napus L.) production: a critical review. Australian Journal of Crop Science, 13(01), 88-97.

EL Sabagh, A., Hossain, A., Islam, MS., Barutçular, C., Ratnasekera, D., Kumar, N., Meena, R.S. Gharib, H.S., Saneoka, H., \& Teixeira da Silva, J.A. (2019b). Salinity stress management for sustainable soybean production using foliar application of compatible antioxidants and soil application of organic fertilizers: a critical review. Australian Journal of Crop Science, 13(02), 228-236.

EL Sabagh, A., Hossain, A., Barutçular, C., Gormus, O., Ahmad, Z., Hussain, S., Islam, M. S., Alharby, H., Bamagoos, A., Kumar, N., Akdeniz, A., Fahad, S., Meena, R. S., Abdelhamid, M., Wasaya, A., Hasanuzzaman, M., Sorour, S., \& Saneoka, H. (2019c). Effects of drought stress on the quality of major oilseed crops: implications and possible mitigation strategies - A Review. Applied Ecology and Environmental Research 17(2), 4019-4043. https://doi.org/10.15666/ aeer/1702_40194043

EL Sabagh, A., Hossain A., Islam M.S., Barutcular C., Hussain S., Hasanuzzaman, M., Akram, T., Mubeen, M., Nasim, W., Fahad, S., Kumar, N., Meena, R.S., Kızılgeçi, F., Yıldırım, M., Ratnasekera, D., \& Saneoka, H. (2019d). Drought and salinity stresses in barley: Consequences and mitigation strategies. Australian Journal of Crop Science, 13(06), 810820. https://doi.org/10.21475/ajcs.19.13.06.p1286

EL Sabagh, A., Hossain, A., Barutçular, C., Islam, M. S., Awan, S. I., Galal, A., Iqbal, M. A., Sytar, O., Yildirim, M., Meena, R. S., Fahad, S., Najeeb, U., Konuskan, O., Habib, R. A., Llanes, A., Hussain, S., Farooq, M., Hasanuzzaman, M., Abdelaal, K. H., Hafez, Y.,Cig, F., \& Saneoka, H. (2019e). Wheat (Triticum Aestivum L.) Production Under Drought And Heat Stress - Adverse Effects, Mechanisms And Mitigation: A Review. Applied Ecology And Environmental Research, 17(4), 8307-8332.
FAOSTAT. (2016). The data set "Sugar beet, production quantity (tons)" for Egypt contains data from the year 1961 until 2016. http://www.factfish.com/statistic-country/egypt/ sugar+beet,+production.

Ghoulam, C., Ahmed, F., \& Khalid, F. (2001). Effects of salt stress on growth, inorganic ions and proline accumulation in relation to osmotic adjustment in five sugar beet cultivars. Environmental and Experimental Botany, 47, 139-50. https://doi.org/10.1016/S0098-8472(01)00109-5

Gong, H.J., Zhu, X.Y., Chen, K.M., Wang, S.M., \& Zhang, C.L. (2005). Silicon alleviates oxidative damage of wheat plants in pots under drought. Plant Science, 169, 313-321. https:// doi.org/10.1016/j.plantsci.2005.02.023

Jain, M., Tiwary, S., \& Gadre, R. (2010). Sorbitol-induced changes in various growth and biochemical parameters in maize. Plant, Soil and Environment 56, 263-267. https://doi. org/10.17221/233/2009-PSE

Kang, G.Z., Li, G.Z., Liu, G.Q., Xu, W., Peng, X.Q., Wang, C.Y., Zhu, Y.J., \& Guo, T.C. (2013). Exogenous salicylic acid enhances wheat drought tolerance by influence on the expression of genes related to the ascorbate-glutathione cycle. $B i$ ologia Plantarum, 57(4), 718-724. https://doi.org/10.1007/ s10535-013-0335-z

Khodary, S.E. (2004). Effect of salicylic acid on the growth, photosynthesis and carbohydrate metabolism in salt stressed maize plants. International Journal of Agriculture and Biology, 1, 5-8.

Le Docte, A. (1927). Commercial determination of sugar in beet root using the Sacks Le Docte. International Sugar Journal, 29, 488-492.

Merwad, A.M.A. (2015). Effect of Potassium Fertilisation and Salicylic Acid on Yield, Quality and Nutrient Uptake of Sugar Beet (Beta vulgaris L.) Grown in Saline Soil. Malaysian Journal of Soil Science, 19, 95-105.

Mishra, M., \& Prakash, V. (2013). Impact of foliar application of salicylic acid on growth and lipid peroxidation in water stress tolerance of Glycine max (L.) Merrill. International Journal of Bioassays, 3(01), 1721-1728.

Molla, S.H., Nakasathien, S., Ali, A., Khan, A., Alam, R., Hossain, A., Farooq, M., \& EL Sabagh, A. (2019). Influence of nitrogen application on dry biomass allocation and translocation in two maize varieties under short pre-anthesis and prolonged bracketing flowering periods of drought. Archives of Agronomy and Soil Science, 65(7), 928-944. https:// doi.org/10.1080/03650340.2018.1538557

Moosavi, S.G. (2012). The effect of water deficit stress and nitrogen fertilizer levels on morphology traits, yield and leaf area index in maize. Pakistan Journal of Botany, 44, 13511355.

O'Mahony M, 1986. Sensory Evaluation of Food: Statistical Methods and Procedures. CRC Press. pp 487.

Nafei, A.I., Osman, A.M.H., \& Maha M. El. Zeny (2010). Effect of plant densities and potassium fertilization rates on yield and quality of sugar beet crop in sandy reclaimed soils. Journal of Plant Production, Mansoura University, 1(2), 229-237.

Neseim, M.R, Amin, A.Y., \& El-Mohammady, M.M.S. (2014). Effect of potassium applied with foliar spray of yeast on sugar beet growth and yield under drought stress. Global 
Advanced Research Journal of Agricultural Science, 3(8), 211-222.

Noreen, S., Fatima, K., Athar, H.U.R., Ahmad, S., \& Hussain, K. (2017a). Enhancement of physio-biochemical parameters of wheat through exogenous application of salicylic acid under drought stress. Journal of Animal and Plant Science, 27(1), 153-163.

Noreen, S., Siddiq, A., Hussain, K., Ahmad, S., \& Hasanuzzaman, M. (2017b). Foliar application of salicylic acid with salinity stress on physiological and biochemical attributes of sunflower (Helianthus annuus L.) crop. Acta Scientiarum Polonorum-Hortorum Cultus, 16(2), 57-74.

Noreen, S., Ashraf, M., Hiussain M., \& Amer, A.J. (2009). Exogenous application of salycilic acid enhances antioxidative capacity in salt stressed sunflower (Helianthus annuus L.). Pakistan Journal of Botany, 41, 473-479.

Omar, A.M., Hamed, O.M.A., Abolela, M.F.KH.A., Islam, M.S., \& EL Sabagh,A. (2019a.) Bio-nitrogen Fertilization and Leaf Defoliation Increased Yield and Quality of Sugar Beet. Asian Journal of Applied Sciences, 12, 29-36. https://doi. org/10.3923/ajaps.2019.29.36

Omar, A.M., El-Menshawy, M., El-Okkiah, S.A., \& EL Sabbagh, A. (2019b). Foliar Application of Osmoprotectants Stimulate Cotton (Gossypium barbadense L.) to Survive under Late Sown Stress Condition. Open Agriculture, 3(1), 684697. https://doi.org/10.1515/opag-2018-0072

Ramadan, B.S.H. (1999). Effect of period between last irrigation and harvest date on yield and quality of some sugar beet varieties (Beta vulgaris L.). Egyptian Journal of Applied Science, 14(10), 82-95.

Ramazan, C. (2002). Root yield and quality of sugarbeet in relation to sowing date, plant population and harvesting date interactions. Turkish Journal Agriculture, 26, 133-39.

Saneoka, H., Moghaieb, R.E.A., Premachandra, G.S., \& Fujita, K. (2004). Nitrogen nutrition and water stress effects on cell membrane stability and leaf water relations in Agrostis palustris Huds. Environmental Experimental Botany, 52, 131-138. https://doi.org/10.1016/j.envexpbot.2004.01.011

Seadh, S.E., Attia, A.N., Said, E.M., El-Maghraby, S.S., \& Ibrahim, M.E.M. (2013). Productivity and quality of sugar beet as affecting by sowing methods, weed control treatments and Nitrogen fertilizer levels. Pakistan Journal of Biological Sciences, 16(15), 711-717. https://doi.org/10.3923/ pjbs.2013.711.719

Shalaby, N.M.E., Osman, A.M.H., \& EL-Labbody, A.H.S.A. (2011). Relative performance of some sugar beet varieties under three plant densities in newly reclaimed soil. Egyptian Journal of Agricultural Research, 89(1), 291-299.

Sohrabi, Y., \& Heidari, G. (2008). Influence of withholding irrigation and harvest times on yield and quality of sugar beet (Beta vulgaris L.). International Journal of Agriculture and Biology, 10(4), 427-431

Todaka, D., Nakashima, K., Shinozaki, K., \& Yamaguchi-Shinozaki, K. (2012). Toward understanding transcriptional regulatory networks in abiotic stress responses and tolerance in rice. Rice, 5(6), 2-9. https://doi.org/10.1186/19398433-5-6

Yassin, M., EL Sabagh, A., Mekawy, A.M.M., Islam, M.S., Hossain, A., Barutcular, C., Alharby, H., Bamagoos, A., Liu, L., Ueda, A., \& Saneoka, H. (2019). Comparative performance of two bread wheat (Triticum aestivum L.) Genotypes Under Salinity Stress. Applied Ecology and Environmental Research, 17(2), 5029-041. https://doi.org/10.15666/ aeer/1702_50295041

Zhou, X.M., Mackeuzie, A.F., Madramootoo, C.A., \& Smith, D.L.J. (1999). Effects of some injected plant growth regulators, with or without sucrose, on grain production, biomass and photosynthetic activity of field-grown corn plants. Journal of Agronomy and Crop Science, 183, 103-110. https://doi.org/10.1046/j.1439-037x.1999.00331.x 